Jpn. J. Hosp. Pharm.

$\left[\begin{array}{ll}\text { 21 (4) } 365-369 \text { (1995) } \\ \text { 料 }\end{array}\right]$

\title{
HPLC による血中ミコナゾール港度測定法の検討と臨床応用
}

\author{
長谷川洋一 ${ }^{*}{ }^{1}$, 野呂岳志 ${ }^{1}$, 水野宗道 ${ }^{1}$, \\ 近藤栄治 $\dagger^{2}$, 服部満美子 $\uparrow^{2}$, 中原洋介 $\dagger^{2}$, \\ 津下圭太郎 $\dagger^{2}$, 内海 真 $\dagger^{2}$, 田中正夫 $\dagger^{2}$ \\ 国立名古屋病院葲剂科 $t^{1}$, 同血液内科 $\dagger^{2}$
}

\section{Measurement of Miconazole Serum Concentration in High-performance Liquid Chromatography}

\author{
YOICHI HASEGAWA* ${ }^{* 1}$, TAKESHI NORO ${ }^{+1}$, MUNEMICHI MIZUNO ${ }^{+1}$, \\ EIJI KONDO ${ }^{2}$, MAMIKO HATTORI ${ }^{2}$, YOSUKE NAKAHARA ${ }^{2}$, \\ KeITARO Tsushita $\dagger^{2}$, MAKoto UTSUMI $\dagger^{2}$ and MASAO TANAKA ${ }^{2}$ \\ Department of Pharmacy, National Nagoya Hospital ${ }^{1}$ \\ Blood Disease Center, National Nagoya Hospital†?
}

(Received October 7, 1994 )

(Accepted May 15, 1995 )

\begin{abstract}
Miconazole (MCZ) serum concentration was measured by high-performance liquid chromatography (HPLC). We assessed whether the internal standard method produced on intra-assay error, and found that the method gave more precise and more reproducible results than absolute calibration curve method. With $0.5 \mu \mathrm{g} / \mathrm{ml}$ of $\mathrm{MCZ}$, the coefficient of variation produced by that method was $3.41 \%$, whereas that of the absolute calibration curve method was $5.20 \%$. The concentrations of absolute calibration curve method showed higher values than the internal standard method. This indicated that the internal standard method was far more precise in measuring the $\mathrm{MCZ}$ serum concentrations than was the absolute calibration curve method.
\end{abstract}

Keywords - miconazole (MCZ), high-performance liquid chromatography (HPLC), absolute calibration curve method, internal standard method

\section{はじめに}

造血器疾患に打いて合併する真菌感染症は, 重 篤かつ致死的な経過をとることで問題である.し たがって, 真菌感染症の早期猃断が望まれ, 抗真 菌剂の適正な使用と ${ }^{1-3)}$, 真菌症の予防も重要であ る.

ミコナゾール (MCZ) は抗菌活性に優れ, 耐性

$\dagger^{1,2}$ 名古屋市中区三の丸4-1-1；4-1-1, Sannomaru, Naka-ku, Nagoya, 460 Japan
を獲得しにくい薬剤として繁用されている.そこ で，MCZ の血清中濃度測定法について内部標準 法を用いた測定法を検討し，24時間持続点滴投与 法における血清中濃度測定に適用した。

\section{実験材料および方法}

\section{1. 試薬}

$\mathrm{MCZ}$ の標準品は持田製薬株式会社より恵与さ れ, 内部標準物質の Econazole (以下 ECZ) は SIGMA 社製を，そしてジェチルェーテルは片山 
化学工業製を用いた。

アセトニトリル，メタノールは片山化学工業製 HPL C用を用い, Mobile Phase Modifier とし $\tau$ Radial-Pak Reagent D4 (Di-Butyl Amine Phosphate：以下 D4）は Waters 製のものを 使用した.

添加血清は BIO-RAD 社製の Drug Free Serum Lyphochek を用いた。

\section{2. 測定方法}

1）検体処理

血清 $1 \mathrm{ml}$ 括よび内部標準物質 (ECZ) $100 \mu \mathrm{l}(10$ $\mu \mathrm{g} / \mathrm{ml}$ ) を正確に $10 \mathrm{ml}$ 共栓試験管にとり，水 1 $\mathrm{ml}$ および $2 \mathrm{~N}-\mathrm{NaOH}$ 溶液 $0.1 \mathrm{ml}$ を加えて混合 し，更にジェチルェーテル $5 \mathrm{ml}$ を正確に加えて， 振とら機で10分間振とうした．2000rpm，5分間 遠心分離後, ジェチルェーテル層 $4 \mathrm{ml}$ を正確に カルチャーチューブに分取し， $40^{\circ} \mathrm{C}$ で蒸発乾固 した. 冷却後, 残渣にメタノール $0.2 \mathrm{ml}$ を加兄 て溶解しそその $20 \mu \mathrm{l}$ を測定試料とした，絶対検 量線法は内部標準物質を加えず同様に抽出を行っ た.

\section{2) HPLC}

ポンプは Waters 510 HPLC Pump, 検出器は Waters 484 Tunable Absorbance Detector,
カラムヒータは Waters RCM-100, 試料注入は Waters WISP 710B, 定量計算には Waters QA-1 ${ }^{\mathrm{TM}}$ Data System を用いた。

カラムは Waters : Nova Pack C18 (8mm× $10 \mathrm{~cm}$ ）を使用した。移動相は $10 \mathrm{mM} \mathrm{D} 4 / \mathrm{MeOH}$ $(200 / 800, \mathrm{v} / \mathrm{v})$ を用い, 流速 $1.0 \mathrm{ml} / \mathrm{min}$, カラ ム温度 $50^{\circ} \mathrm{C}, 230 \mathrm{~nm}(0.32 \mathrm{AUFS})$ で検出した。

3） 精度

$0.5,1,2,5,10 \mu \mathrm{g} / \mathrm{ml}$ の濃度になるよう $\mathrm{MCZ}$ を Drug Free Serum に添加した. 各濃度につ き 5 回測定し, 絶対検量線法括よび内部標準法に ついて各々の回収率，再現性を調べ，比較した。

\section{24時間持続点滴投与法}

1）患者

腎機能，肝機能の正常な悪性りンパ腫および急 性骨髄性白血病の患者で, 化学療法治療中の深在 性真菌症が疑われる中心静脈栄養 (以下 IVH) 施 行患者 2 例を被検者とした。

2) 薬剤投与計画

$\mathrm{MCZ}$ (フロリードF 注) 1200mgをハイカリッ ク 2 号, プロテアミン $12 \mathrm{X}$, ネオラミンマルチ, アデラビン 9 号およびヶイッーNを配合した高カ ロリ一輸液内に混合し，24時間の IVH 投与を 7 日間行った。

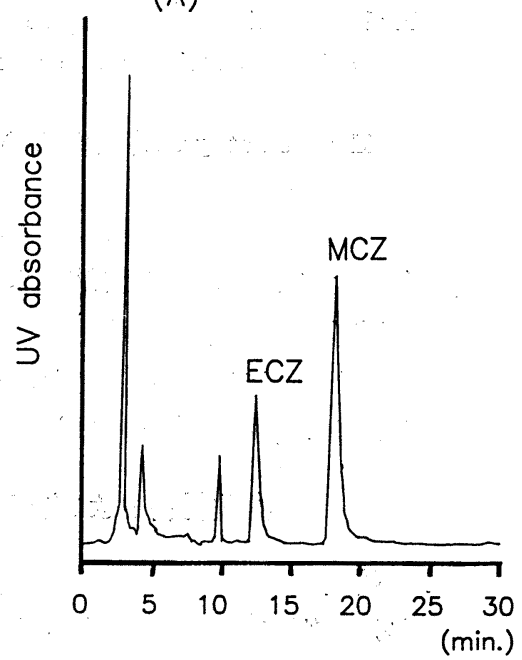

(B)

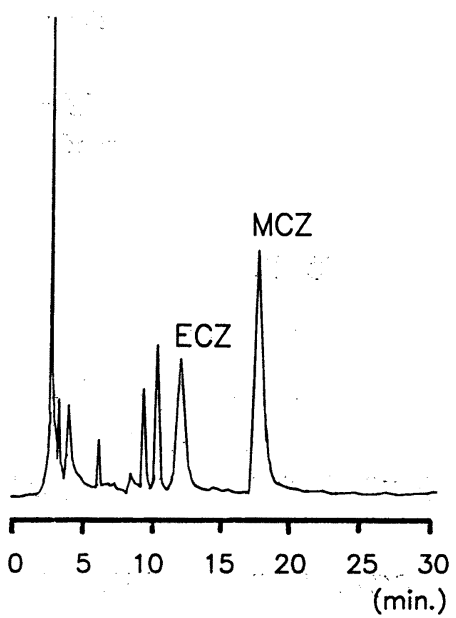

Fig. 1. Chromatogram of Miconazole (MCZ) from (A) Standard Solution, and (B) Patient Serum 
3）採血

持続点滴開始から $1,2,4,6,10,18,24$ (1 日), 48 (2 日), 96 ( 4 日), 168 (7 日) 時間後 の計 9 ポイント採血を行った。採血は血清分離剤 を含まない採血管にて全血を採取し，3000 rpm， 5 分間遠心分離後, 得られた血清を測定検体に用 いた.

\section{結果}

\section{1. 精度}

本法により得られたクロマトグラムは, Fig. 1 に示した. 絶対検量線法に基づく回収率（Table 1) は, 平均 $103.85 \%$ で, 変動係数は $0.5 \mu \mathrm{g} / \mathrm{ml}$ の5. 20\%が最も大きかった.ささらに, 0 10 $\mu \mathrm{g} / \mathrm{ml}$ において相関係数 0.9983 , 回帰式 $\mathrm{y}=1.075 \times 10^{-6}$ $\times ー 0.045$ の直線性が認められた（Fig. 2).

内部標準法による結果は, 変動係数が最も高い
ものでも $3.41 \%$ と絶対検量線法に比べ小さかった (Table 2). 回収率は, 平均 $102.66 \%$ の結果とな った.また, $0 〜 10 \mu \mathrm{g} / \mathrm{ml}$ において相関係数 0.9999 , 回㷌式 $\mathrm{y}=1.011 \times-0.011$ の直線性が認められた (Fig. 3).

\section{24時間持続点滴投与法}

血清中 $\mathrm{MCZ}$ 濃度を 2 症例について測定した。 症例 1 では48時間後まで血清中濃度が上昇し続け その後低下する傾向が認められた。しかし，96時 間以降 168 時間後まで次第に血清中 $\mathrm{MCZ}$ 濃度が 低下する傾向が認められた（Fig. 4). また，症 例 2 では，投与後12時間でほぼ定常状態に達した (Fig. 5)．２症例とも絶対検量線に基づく濃度は 本法に比べ濃度が高くなる傾向が認められた。

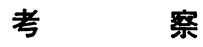

絶対検量線に基づく $\mathrm{MCZ}$ の血中濃 度 測 定 法

Table 1. Precision of HPLC in Drug Free Serum Spiked MCZ

\begin{tabular}{ccccr}
\hline $\begin{array}{c}\text { conc. } \\
(\mu g / \mathrm{m} 1)\end{array}$ & $\begin{array}{c}\text { mean } \\
(\mu \mathrm{g} / \mathrm{m} 1)\end{array}$ & $\begin{array}{c}\text { S. D. } \\
(\mu g / \mathrm{ml})\end{array}$ & $\begin{array}{l}\text { C. V. } \\
(\%)\end{array}$ & $\begin{array}{c}\text { recovery } \\
(\%)\end{array}$ \\
\hline 0.5 & 0.48 & 0.03 & 5.20 & 102.00 \\
1 & 1.02 & 0.03 & 3.29 & 107.17 \\
2 & 2.07 & 0.08 & 3.83 & 101.49 \\
5 & 5.19 & 0.17 & 3.24 & 98.90 \\
10 & 10.83 & 0.35 & 3.18 & 109.69 \\
\hline
\end{tabular}

$\mathrm{n}=5$

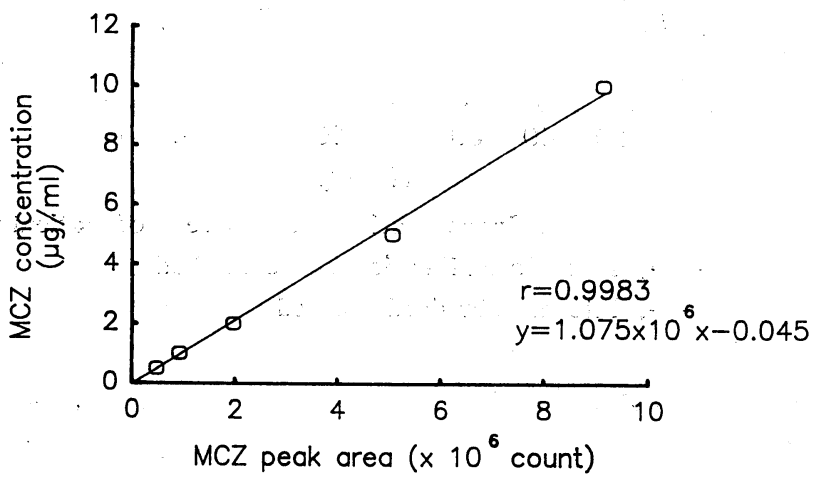

Fig. 2. Standard Curve from Drug Free Serum Spiked with MCZ 
Table 2. Precision of HPLC in Drug Free Serum Spiked MCZ with Internal Standard

\begin{tabular}{llllr}
\hline $\begin{array}{c}\text { conc. } \\
(\mu g / \mathrm{ml})\end{array}$ & $\begin{array}{c}\text { mean } \\
(\mu g / \mathrm{ml})\end{array}$ & $\begin{array}{c}\text { S. D. } \\
(\mu g / \mathrm{ml})\end{array}$ & $\begin{array}{l}\text { C. v. } \\
(\%)\end{array}$ & $\begin{array}{c}\text { recovery } \\
(\%)\end{array}$ \\
\hline 0.5 & 0.49 & 0.02 & 3.41 & 96.15 \\
1 & 0.92 & 0.03 & 3.03 & 109.10 \\
2 & 1.98 & 0.07 & 3.34 & 102.47 \\
5 & 4.94 & 0.10 & 2.11 & 105.61 \\
10 & 9.88 & 0.17 & 1.71 & 99.99 \\
\hline
\end{tabular}

$n=5$

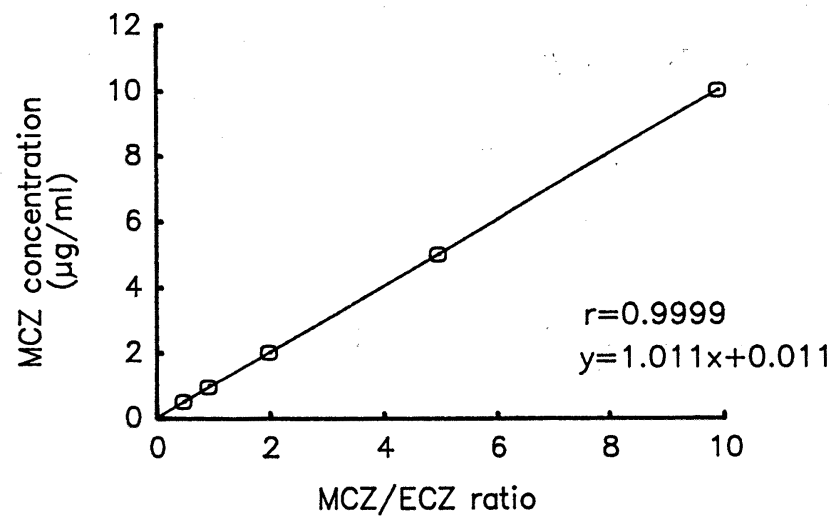

Fig. 3. Standard Curve from Drug Free Serum Spiked with $\mathrm{MCZ}$ and ECZ as Internal Standard

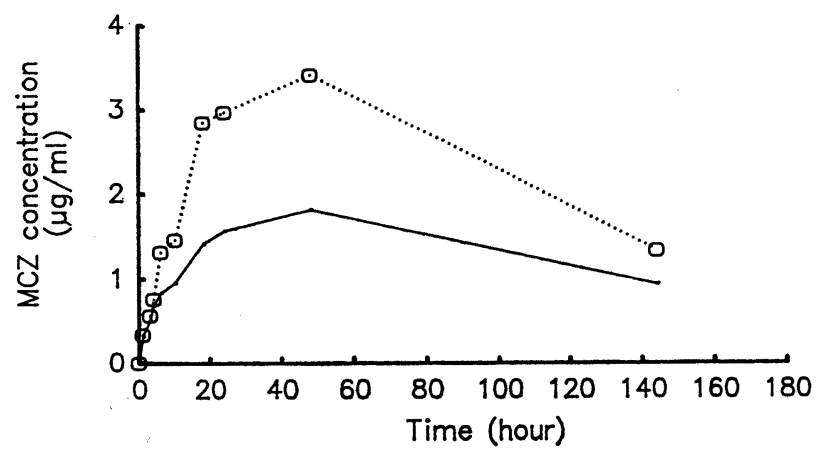

Fig. 4. MCZ Serum Concentration from Case 1 of Patients ....., absolute calibration curve method - internal standard method

は，その抽出過程でジェチルエーテルを使用する など溶媒の高い揮発性から測定者や測定時期によ る値の誤差が生じる可能性が考えられた。 そこで 内部標準法による血清中 MCZ 濃度測定法を検討
した. 内部標準法では変動係数は小さいが, 絶対 検量線法に基づく濃度に比べ低值を示した。これ は, 変動係数のバラツキが大きかった絶対検量線 法に比べ, バラッキの小さい内部標準法による值 


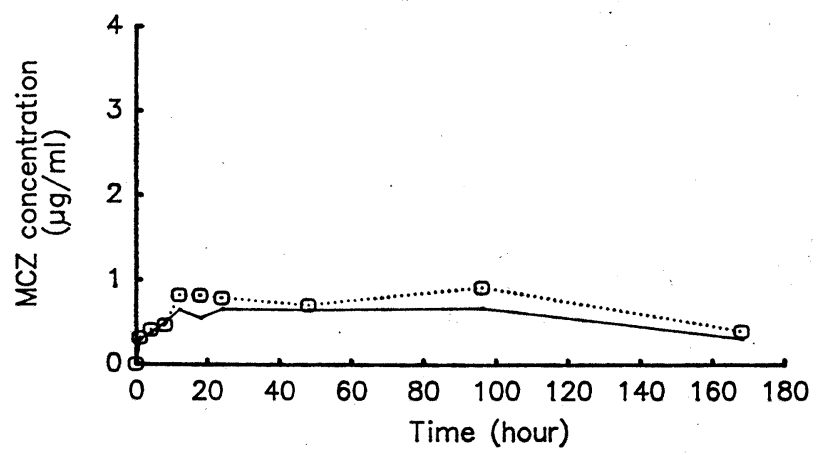

Fig. 5. MCZ Serum Concentration from Case 2 of Patients ......, absolute calibration curve method

- internal standard method

の方が測定値の信頼度が高いと考えられる．さら に, MCZ の MIC は, 菌種によっても異なるが $0.04 \sim 5 \mu \mathrm{g} / \mathrm{ml}$ 以下4) であり, 濃度的にも低濃度 域であることから，変動係数のバラッキが大きい 絶対検量線法より内部標準法を用いて測定を行う 方が臨床的に意義があると考えられる．

次に，実際の投与法であるが一般には，生食ま たは $5 \%$ ブドウ糖液に希釈し，初回 $200 \mathrm{mg} よ り$ 開始し, 以後 1 回 $200 \sim 400 \mathrm{mg}$ を 1 日 $1 \sim 3$ 回, 30〜60分以上かけて点滴静注することになってい る. しかし, 悪心・嘔吐等の副作用の発現頻度が 高い。そこで, MIC 以上の濃度を持続的に維持 させること，副作用を軽減することを目標に， IVH からの24時間持続点滴投与を試みた。今回, 報告した 2 症例はいずれも血液疾患の癌化学療法 実施後の重症感染症を併発し, 起因菌の同定がで きなかった症例である．2症例における絶対検量 線法に基づく值は，内部標準法による值に比べて 高值を示す傾向が認められた．また，いずれの症
例も MIC 濃度に達しており，かつ悪心・嘔吐は 認められず，順調に経過した．悪心・嘔吐が投与 法や血中濃度と相関するとすれば $\mathrm{MCZ}$ の血清中 濃度の測定は，MIC を測定することと同様に意 義があると考えられる，今後，副作用と血清中濃 度との相関性を検討することが望まれる。

\section{文南}

1）佐野元春, 秋本佳久, 坂下暁子, 中牧 剛, 日野 研一郎, 鈴木和郎, 友安 茂, 鶴岡延喜, 化学療 法の領域, 5, 119-124 (1989).

2）日野研一郎, 松田 功, 山田一成, 久武純一, 横 山明弘, 佐野元春, 友安 茂, 鶴岡延熹, 化学療 法の領域, 9, 138-143 (1993).

3）影山慎一, 西井一浩, 片山直之, 田中 泉, 豊田 英樹, 南川光三, 脇田喜弘, 和田英夫, 西川政 勝, 小林 透, 南 信行, 出口克己, 白川 茂, 新薬と臨床, 42, 1438-1440 (1993).

4）平谷民雄, 山口英世, Chemotherapy，32，534540 (1984). 